\title{
Characterization of X-ray-generated floral mutants carrying deletions at the $S$-locus of distylous Turnera subulata
}

\author{
JDJ Labonne ${ }^{1}$, F Tamari ${ }^{2}$ and JS Shore ${ }^{1}$ \\ ${ }^{1}$ Department of Biology, York University, Toronto, Ontario, Canada and ${ }^{2}$ Department of Biological Sciences, Kingsborough Community \\ College, CUNY, Brooklyn, NY, USA
}

\begin{abstract}
To investigate the genetic architecture of distyly in Turnera subulata and test the hypothesis that a supergene determines distyly, we used X-ray mutagenesis to generate floral mutants. Based upon the crossing design, all progeny were expected to be short-styled. Of 3982 progeny screened, 10 long-styled mutants, one long homostyle and one short homostyle were recovered. Assays for molecular markers tightly linked to the $S$-locus showed that the mutants were missing 1-3 markers indicating they are deletion mutants. We investigated the incompatibility phenotype of the mutants and found that both their styles and pollen behaved like those of the long-styled morph. There was a variation in the absolute length of styles, stamens and pollen size of the long-styled mutants. Furthermore, long-styled mutants
\end{abstract}

possessing larger deletions tended to have their anthers and stigmas in closer proximity. We explored the inheritance of the $S$-locus mutations and found that only one of the deletion mutations was transmitted to progeny where we recovered seven such progeny. Remarkably, our data are consistent with the supergene model (GPA/gpa) of Primula. The long homostyle mutant appears to have deletions involving both the $G$ and $P$ loci. The other mutants appear to have deletions of the entire $S$-locus. The mutants generated will serve as a valuable resource for the molecular dissection of the $S$-locus region, and in the identification of genes determining distyly.

Heredity (2010) 105, 235-243; doi:10.1038/hdy.2010.39; published online 14 April 2010

Keywords: Turnera; distyly; X-ray mutagenesis; S-locus deletion; floral mutants

\section{Introduction}

The reciprocal arrangement of reproductive organs and self-incompatibility (SI) system of distylous species appears to be determined by a series of tightly linked genes forming a supergene. This inheritance pattern was first proposed for the genus Primula, where there is evidence that three to five, or more, linked genes occur (Ernst, 1955; Dowrick, 1956; Lewis and Jones, 1992; Kurian and Richards, 1997; Barrett and Shore, 2008). There is more limited evidence supporting the occurrence of a supergene in lineages outside the Primulaceae that have independently evolved distyly, including Fagopyrum (Woo et al., 1999; Matsui et al., 2003; Fesenko et al., 2006; Wang et al., 2005) and Turnera, where the inheritance of self-compatible homostyles has been investigated (Shore and Barrett, 1985; Barrett and Shore, 1987; Tamari et al., 2001, 2005).

An approach to testing the hypothesis that a supergene determines distyly, is to generate and characterize mutants. Mutational studies have proven useful in the study of homomorphic SI systems (de Nettancourt, 1977; Golz et al., 2000) but there appears to have been no

Correspondence: Dr JS Shore, Department of Biology, York University, 4700 Keele Street, Toronto, Ontario, Canada M3J 1P3.

E-mail:shore@yorku.ca

Received 21 September 2009; revised 30 January 2010; accepted 11 March 2010; published online 14 April 2010 systematic investigation of distylous species using this approach. A few mutants have, however, been generated and explored in distylous Fagopyrum esculentum (Sharma and Boyes, 1961; Nomura et al., 2002). Under the commonly held supergene model of Primula spp., three genes tightly linked in coupling, GPA/gpa, determine the inheritance of distyly. Thus, it should be possible to mutate, or delete the component genes yielding predictable phenotypes, that should appear to be inherited as new alleles of the $S$-locus. Importantly, the generation of deletion mutants will aid efforts to positionally clone the genes determining distyly by delimiting the genomic regions containing the genes.

In this paper, we use X-ray mutagenesis to generate 12 floral mutants of Turnera subulata. We provide evidence that the mutants involve deletions of the S-locus, or portions thereof. We characterize the floral and incompatibility phenotype of the mutants and attempt to explore their inheritance. We discuss the significance of the mutants to the genetic architecture of distyly and in positional cloning.

\section{Materials and methods}

\section{X-ray mutagenesis and mutant screen}

We used two plants of diploid Turnera subulata, a longstyled plant (S16L, homozygous recessive, ss) and F60SS, a short-styled plant homozygous, $S S$, at the $S$-locus. 

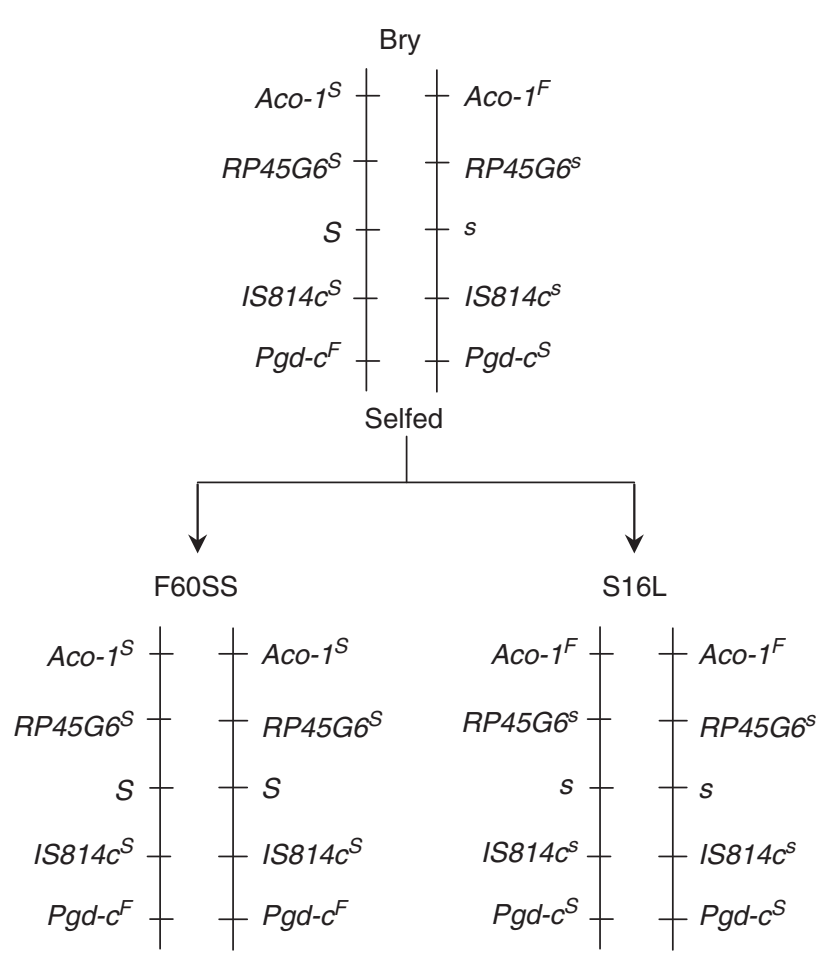

X-ray irradiate pollen

Ovule parent

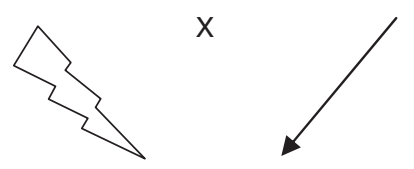

Screen numerous $M_{1}$ progeny for flowers that are not short-styled.

Figure 1 Crossing scheme to produce mutants. Genotypes of parental plants are given for the $S$-locus and four additional linked loci.

Both plants were produced by selfing an unusual selfcompatible short-styled parental plant termed Bry. Genotypes of the parental plants at the $S$-locus and four marker loci are provided (Figure 1). Further details of Bry may be found in Athanasiou and Shore (1997) and Labonne et al. (2009). We rooted multiple stem cuttings of both plants (S16L and F60SS) to increase the number of flowers available for pollinations and seed production.

On mornings when pollen was to be irradiated, we collected anthers from the short-styled plant F60SS in a Petrie plate and irradiated them with various doses of X-rays using a Willick Xplorer $160 \mathrm{CP} 3.2 \mathrm{~kW}$ system (Willick Engineering, Santa Fe Springs, CA, USA). Anthers were irradiated using the maximum output of the X-ray machine ( $160 \mathrm{KVp}$ and $18.9 \mathrm{~mA})$, with varying times of exposure (20-180 s). This yielded doses ranging from $\sim 3.7$ to 33.6 Gy. A pilot study was carried out in the year 2001 using a Philips MG-100 X-ray machine (Philips Electronic Instruments) and irradiating anthers with $\sim 45 \mathrm{~Gy}$. We then used the irradiated anthers to pollinate the long-styled plant, S16L, using a pair of forceps to brush 2-3 anthers across the stigmas of each flower. Seeds were collected from S16L when fruits dehisced ( $\sim 3$ weeks following pollination).

Seeds were sown (100 per pot) and $\sim 3$ weeks following germination, seedlings were transplanted into individual $15 \mathrm{~cm}$ pots. We determined the percent germination for a sample of 62 pots $(18.3 \% \pm 0.7)$. The morph of each plant was recorded at flowering, and short-styled plants (non-mutants) were discarded. All other plants (putative mutants) were retained and genomic DNA was extracted from them using the Mini-CTAB protocol of Labonne et al. (2009). Irradiation and mutant screening was carried out in the years 2001 through 2009.

\section{Confirmation of mutant status}

To confirm that the putative floral mutants were not pollen or seed contaminants, we used markers known to be linked in coupling with the $S$-allele (Figure 1). These included, initially (2001 pilot study) two isozyme loci, Aco-1 and Pgd-c, known to flank the S-locus at distances of 5.7 and $9.1 \mathrm{cM}$, respectively (Labonne et al., 2007). Putative mutants from the later screens were assayed using a dominant inter-simple sequence repeat marker, $I S 814 \mathrm{C}$, and a dominant random amplified microsatellite polymorphism marker, RP45G6 (Figure 1). These markers lie on opposite sides of the $S$-locus at distances of 1.1 and $3.3 \mathrm{cM}$, respectively (Labonne et al., 2008). Markers IS814c and RP45G6 were assayed following Labonne et al. (2008). Mutants are expected to be heterozygous for these markers.

Once it was confirmed that these plants were indeed mutants (and not the result of pollen or seed contamination), we determined whether they possessed a dominant marker, RP81E18, known to co-segregate with the S-allele (Labonne et al., 2008, 2009). We used the end sequences of RP81E18 to design new primers (RPE18F3: 5'-GGACTGCAGAG-3' and RPE18R3: 5'-GGGTGGGTG C $\left.-3^{\prime}\right)$ to increase the level of amplification of RP81E18 thereby facilitating scoring of this marker. The PCR cocktail consisted of $1 \mu \mathrm{l}$ of DNA $(\sim 25 \mathrm{ng}), 1.0 \mu \mathrm{l}$ of each primer $(10 \mathrm{pmol}), 2.75 \mu \mathrm{l}$ of $\mathrm{ddH}_{2} \mathrm{O}$ and $6.25 \mu \mathrm{l}$ of JumpStart REDTaq Ready mix DNA polymerase (SigmaAldrich Inc., Oakville, ON, Canada) in a total volume of $12.0 \mu \mathrm{l}$. The PCR machine was programmed for a $2 \mathrm{~min}$ initial denaturation followed by 35 cycles of $94^{\circ} \mathrm{C}$ for $50 \mathrm{~s}, 37^{\circ} \mathrm{C}$ for $25 \mathrm{~s}, 72{ }^{\circ} \mathrm{C}$ for $85 \mathrm{~s}$ and a final extension step of $3 \mathrm{~min}$ at $72^{\circ} \mathrm{C}$. Amplification products were run on $7.5 \%$ polyacrylamide gels for $65 \mathrm{~min}$ and silver-stained following Labonne et al. (2008).

\section{Phenotype of mutants}

We determined the morph of each mutant. We also measured a number of floral characters for 10 replicate flowers to the nearest $0.1 \mathrm{~mm}$ using vernier calipers. We measured both style and stamen lengths from the base of the ovary, and petal length as a measure of flower size. We calculated stigma-anther separation as the difference between style length and stamen length. We measured the length of 20 freshly collected dry pollen grains using a calibrated ocular micrometer on a compound light microscope. The mutants show varying levels of pollen sterility. To avoid measuring the typically smaller sterile grains, we measured only pollen grains that possessed a normal shape. Mutants L1 and SH1 were highly pollen sterile and we were only able to find and measure 6 and 16 pollen grains for each, respectively. We estimated pollen fertility by staining pollen with aniline blue in lactophenol, and scoring stainability for 200 grains from 
each of three flowers per plant. We determined seed set per pollination for the mutants by pollinating 10 flowers from each mutant (with the exception of $\mathrm{SH} 1$ where only four flowers were pollinated) with compatible pollen from one of the parental plants and counted seed production.

We assessed the incompatibility phenotype of both pollen and styles for each mutant. We pollinated each mutant with pollen from a long- and short-styled plant (S16L and Bry). We also used pollen of the mutants to pollinate a long-styled plant (S16L) as well as a selfincompatible short-styled plant of T. scabra (since Bry is self-compatible due to the lack of incompatibility in its style, it was not useful for this purpose). We carried out two replicate pollinations of each type above and collected and fixed the styles (three per flower pollinated) in 3 ethanol: 1 acetic acid $24 \mathrm{~h}$ after pollination. We stained the styles in aniline blue and observed pollen tubes using fluorescence microscopy following Tamari et al. (2001).

We used analysis of variance (ANOVA) followed by Tukey's studentized range test for multiple comparisons, to determine whether there were significant differences among the mutants for various reproductive characters. We included the parental plants in the analyses when appropriate. In some analyses we controlled for flower size, using petal length as a covariate in analyses of covariance. Both paired and two-sample $t$-tests were carried where indicated. An arcsine transformation was applied to pollen fertility data and a log transformation was applied to seed set data. Analyses were carried out using SAS 9.1 software (SAS Institute Inc. (2004)).

\section{Detection of polygalacturonase and $\alpha$-dioxygenase}

Immunoblotting was used to determine whether the styles of the mutants possessed a polygalacturonase (Athanasiou et al., 2003) and an $\alpha$-dioxygenase (Khosravi et al., 2004), both known to be specific to styles of shortstyled plants. We collected styles from newly opened flowers of each mutant as well as the parental plants (as controls). We then carried out sodium dodecylsulfatepolyacrylamide gel electrophoresis and immunoblotting to detect each of the proteins, following previous protocols (Athanasiou et al., 2003; Khosravi et al., 2004). Mutant SH1 flowers infrequently as many floral buds abscise before anthesis. Unfortunately, we were unable to obtain freshly collected styles to assay the presence or absence of these proteins for SH1.

\section{Inheritance of mutations}

We crossed the mutants as pollen and/or ovule parents to S16L, F60SS and/or Bry, depending on their morph, incompatibility behaviour and degree of pollen or seed sterility. Some of the mutants set no seeds as ovule parents. We recorded the phenotype of the resulting progeny at flowering. For mutants L1 and LH1, which were obtained from the pilot study of 2001, we assayed progeny for both linked isozyme markers, Aco-1 and Pgd-c, following methods of Athanasiou and Shore (1997). For all other progeny, we extracted DNA as above. We then performed PCR to amplify co-dominant marker P9SP1 from each progeny. This marker has recently been identified in our lab during chromosome walking and it is located at $0.05 \mathrm{cM}$ on the distal side of the $S$-locus
(Labonne JDJ and Shore JS, unpublished data). Genotyping progeny with marker P9SP1 allowed us to determine with high probability whether the mutant allele had been transmitted to progeny. In some cases, further assays with other $S$-linked markers located on opposite sides of the $S$-locus were required to confirm inheritance for long-styled progeny.

For crosses involving mutants for which the P9SP1 marker has been deleted, we assayed long-styled progeny directly with marker IS814c (proximal side of the S-locus; Figure 1). For long-styled progeny for which only the S-linked marker IS814c amplified, we further assayed these plants with a recently identified dominant random amplified microsatellite polymorphism marker (RP95K7) located at $11.7 \mathrm{cM}$ on the opposite (distal) side of the S-locus (Labonne JDJ and Shore JS, unpublished data).

Mutant L22 is interesting because it is a long-styled plant that possesses marker RP81E18 that co-segregates with the $S$-allele (Labonne et al., 2009). For progeny of the cross L $22 \times$ Bry and reciprocal, we assayed short-styled progeny with the co-dominant marker P9SP1 and longstyled progeny with marker RP81E18, to determine whether progeny had inherited the mutation.

Some progeny inherited the mutation of mutant L20. We measured the pollen fertility and pollen size (as above) for all seven progeny that inherited the mutation as well as 27 progeny that did not (as controls). We also used one long- and two short-styled progeny of L20 carrying the deletion and performed reciprocal crosses in an attempt to generate a mutant homozygous for the $S$-locus deletion.

\section{Results}

\section{Identification of $S$-locus mutants}

Pollinations using irradiated pollen from F60SS (homozygous $S S$ at the $S$-locus) crossed onto S16L (ss), yielded a total of 3982 progeny. In the absence of mutation at the $S$-locus, all progeny are expected to be short-styled $(S s)$ (Figure 1). Screening resulted in the identification of 12 mutants including one long homostyle (LH1, Figure 2c), one short homostyle (SH1, Figure 2e) and 10 long-styled mutants (L1, L15, L16, L20-L26).

The 12 mutants recovered show varying sizes of deletions as determined by assays of five $S$-linked markers (Figure 3 and 4). Four mutants have a deletion of only one marker (RP81E18), three have deletions of two markers (RP81E18 and P9SP1), whereas the remaining mutants have deletions of three or more markers (Figure 3). Interestingly, mutant L22 is the only mutant without a deletion of RP81E18, the marker most closely linked to the S-locus.

\section{Incompatibility behaviour of mutants}

The styles of all mutants inhibited pollen tubes when pollinated by the long-styled parental plant S16L. Pollen germinated penetrated the stigma and grew into the styles, but rarely grew more than half the length of the style. Pollen from the short-styled parent Bry, was compatible on all mutants, with pollen tubes growing to the base of styles (Figure 3). Interestingly, the style of the short homostyle mutant (SH1) had the same incompatibility behaviour as the long-styled mutants. 


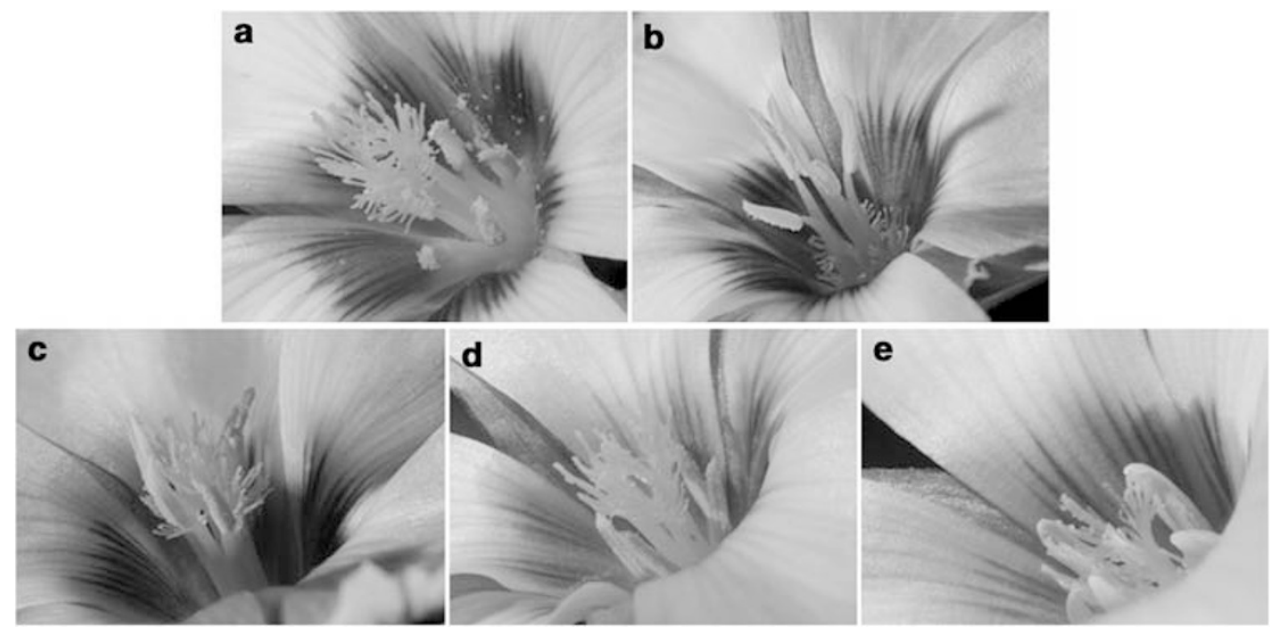

Figure 2 Photographs showing the styles and stamen positions for parental plants and three mutants. (a) Long-styled parent S16L. (b) Shortstyled parent F60SS. (c) Long homostyle mutant LH1. (d) Long-styled mutant L22 with a shorter style than parent S16L. (e) Short homostyle mutant SH1.

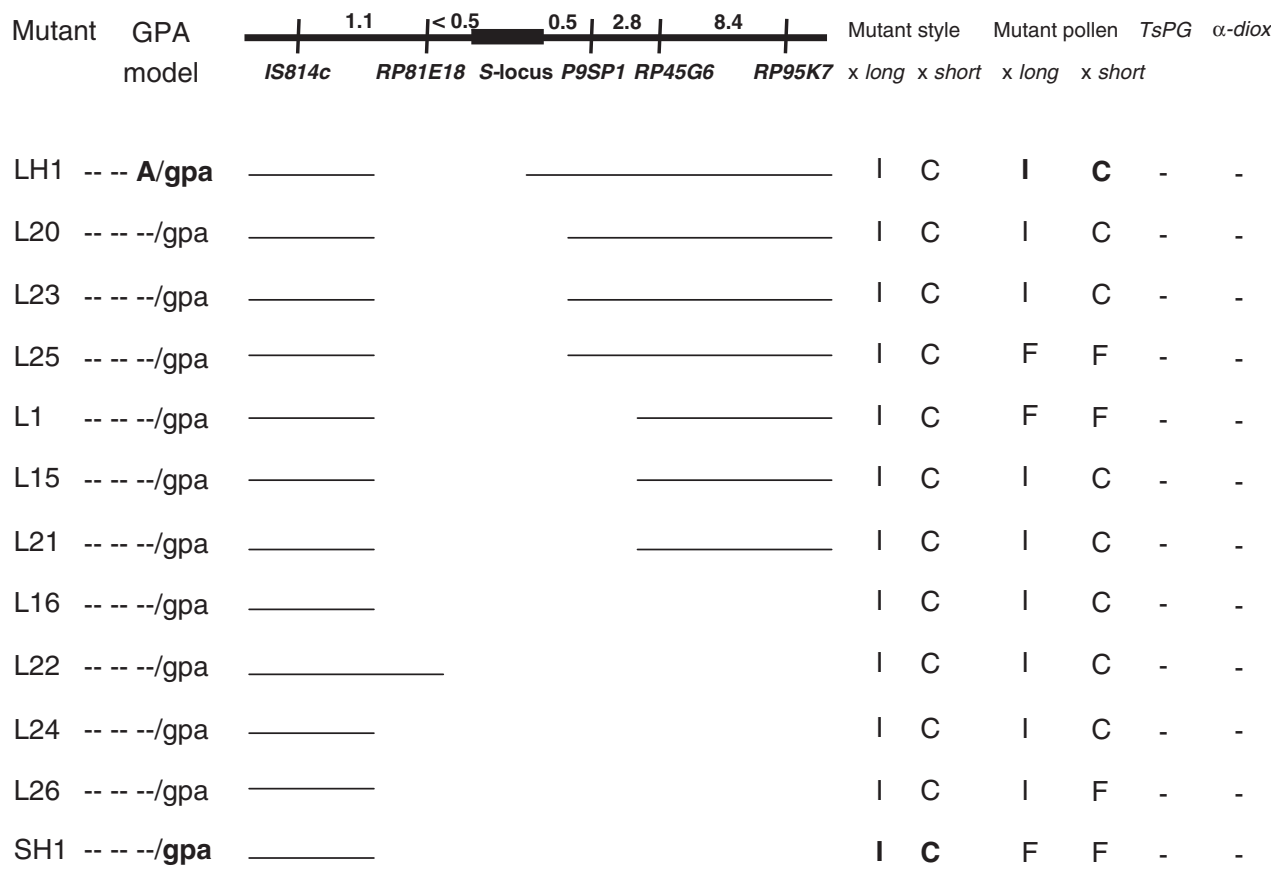

Figure 3 Characterization of 12 S-locus mutants. A genetic map of showing the position of five molecular markers relative to the $S$-locus is provided at the top of the figure. For each mutant, a deletion map is also provided. The genotype at the putative $S$ supergene (two dotted lines indicate deletion of a gene) as well as the incompatibility phenotype of each mutant are shown. Pollen from S16L (long) and Bry (short) were used to investigate the incompatibility behaviour of mutant styles, whereas the phenotypes of mutant pollen were determined using the styles of S16L and short styles of self-incompatible T. scabra. The letter C denotes compatible, with pollen tubes growing to base of style; I-incompatible, with tubes not growing to base of style. F-cannot evaluate compatibility as few or no pollen grains adhere to stigma. TsPG represents the results for the style polygalacturonase whereas $\alpha$-diox denotes the $\alpha$-dioxygenase. The short-style-specific proteins are not expressed in the mutants assayed. Interesting characteristics of some mutants are in bold.

For this mutant, however, pollen of the long-styled parent (S16L) grew as much as $\sim 80 \%$ the length of the style.

Pollen from nine mutants (LH1, L15, L16, L20-L23, L24 and L26) was incompatible on the styles of the longstyled parent, S16L and pollen tubes rarely grew more than $\sim 1 / 3$ the length of the style. We could not assess the incompatibility of pollen for mutants L1, L25 and SH1 on stigmas of S16L and short-styled T. scabra, nor for L26 on stigmas of the short-styled plant. Pollen of these mutants is highly sterile (Figure 5c) and few or no pollen grains adhered to the stigmas (Figure 3). Pollen of the remaining seven long-styled mutants was found to be fully compatible with short-styled, self-incompatible plants of T. scabra. Interestingly, pollen of the long homostyle, LH1, was compatible with short-styled T. scabra (Figure 3).

To explore further the pollen compatibility of mutant LH1, we determined seed set following crosses using pollen of LH1 and pollinating the long- and short-styled 


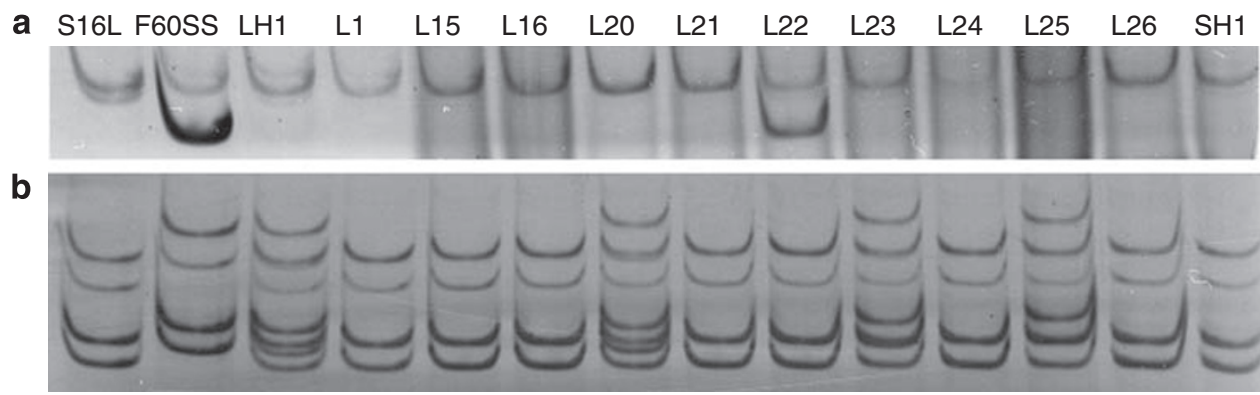

Figure 4 Genotypes of co-segregating marker RP81E18 and co-dominant marker P9SP1 for 12 X-ray mutants as well as two controls (S16L and F60SS). Dominant marker RP81E18 is absent in all but one mutant whereas eight mutants are missing the S-linked bands of co-dominant marker P9SP1.

parental plants (S16L and Bry). The mean seed set per pollination differed significantly for crosses onto the short- $(24.7 \pm 2.1, n=12)$ versus long-styled $(4.4 \pm 1.5$, $n=9)$ parental plants $\left(t_{19}=7.3, P<0.001\right)$.

\section{Distribution of polygalacturonase and $\alpha$-dioxygenase in styles of mutants}

Immunoblotting of a short style-specific polygalacturonase and an $\alpha$-dioxygenase, revealed that none of the mutants expressed either protein in their styles (Figure 3). The short-styled parental plants, Bry and F60SS (controls), expressed both proteins as expected. Mutant SH1 flowers infrequently and, unfortunately, fresh styles could not be included in the assays. Identical results were obtained previously for mutants LH1 and L1 (Khosravi et al., 2003, 2004).

\section{Quantification of reproductive characters}

We quantified a number of reproductive characters of the mutants and parental plants. The mutants differ significantly in flower size as determined by petal length $\left(\mathrm{F}_{14,135}=13.1, \quad P<0.001\right)$ with mutants L23 and L1 possessing the smallest, whereas L24 and L26 had the greatest petal length.

We plotted the reproductive character means ranking the long-styled mutants by decreasing stigma-anther separation (Figure 5a). Styles of the mutants are significantly different in length (Figure 5a). This result held when we excluded the short-styled plants and the short homostyle (SH1) mutant from the analysis $\left(\mathrm{F}_{11,108}=17.2, \quad P<0.001\right)$ and using petal length as a covariate $\left(F_{11,107}=22.7, P<0.001\right)$. Comparable analyses revealed significant differences in stamen length among the mutants (Figure 5a).

There is significant variation for stigma-anther separation among the long-styled mutants (ANOVA results excluding the short-styled parental plants; $F_{12,117}=35.2$, $P<0.001)$. Some mutants, for instance L15, L25 and L23, have their stigmas and anthers well spatially separated in spite of their small flower size (ANCOVA; $\mathrm{F}_{10,98}=17.9$, $P<0.001$ ). Long-styled mutants L15, L20, L23 and L25 do not show a significant difference in stigma-anther separation from their long-styled parent, S16L, whereas the remaining mutants have significantly smaller stigmaanther separations.

Mutant SH1 has its stigmas and anthers in very close proximity (Figure 2e) but the stigma-anther separation differs significantly from zero (mean \pm s.e. $1.1 \pm 0.3 \mathrm{~mm}$; paired $t$-test, $\left.t_{9}=3.8, P<0.005\right)$. The floral phenotype of SH1 is more like that of a short homostyle than a longstyled plant and we have therefore described it as such. The style length of SH1 does not differ significantly from that of its short-styled parent, F60SS, whereas its stamens do not differ from those of the long-styled parent S16L (Figures 2a, 5a).

Mutant LH1 appears to be a 'classic' long homostyle possessing both long styles and long stamens (Figures 2c, 5a) with a stigma-anther separation of $0.1 \pm 0.1 \mathrm{~mm}$, not significantly from zero (paired $t$-test, $t_{9}=0.6, P>0.6$ ). The styles of the LH1 do not differ significantly from those of its long-styled parent, S16L (Figure 5a). The stamens of LH1 $(12.3 \pm 0.4 \mathrm{~mm})$ are significantly greater than those all other mutants and the long-styled parental plant S16L, but are significantly shorter than those of the shortstyled parental plants Bry and F60SS (Figure 5a).

Pollen size showed some interesting differences among the mutants and parental plants. Parental plant F60SS, which is homozygous (SS) at the S-locus, possessed the largest pollen (Figure $5 b$ ) whereas Bry (Ss), had the next largest pollen, which did not differ significantly from pollen of mutants L20, or SH1 (Figure 5b). Mutant LH1 had the next largest pollen, which was significantly smaller than that of the parental short-styled plants (F60SS and Bry), but significantly greater than that of the long-styled parent (S16L) and a number of long-styled mutants (Figure $5 b$ ). Four of the long-styled mutants had pollen that was not significantly different from that of S16L.

To further explore the large pollen size of mutant L20, we measured the pollen size of progeny from crosses involving this mutant (see Inheritance of mutations). The mean pollen size of short-styled progeny with versus without the mutation did not differ significantly (with the mutation: $81.3 \pm 3.3 \mu \mathrm{m}, n=2$; without the mutation: $\left.79.0 \pm 0.4 \mu \mathrm{m}, n=16, t_{16}=1.6, P>0.13\right)$. The mean size of pollen of long-styled progeny with the mutation was $76.8 \pm 0.7 \mu \mathrm{m}(n=5$, range $74.9-79.1 \mu \mathrm{m})$ versus $66.7 \pm$ $0.4 \mu \mathrm{m}(n=11$, range $66.1-68.7 \mu \mathrm{m})$ and differed significantly $\left(t_{14}=13.5, P<0.001\right)$. Long-styled progeny bearing the mutation had a pollen size comparable with that of the L20 mutant and the short-styled parental plants, whereas progeny without the mutation were comparable in size to those of the long-styled parental plant S16L (Figure $5 b$ ).

Pollen fertility of all mutants was relatively poor and differed significantly from the parental plants (Figure 5c). Four mutants (LH1, L15, L21 and L22) had pollen fertility 

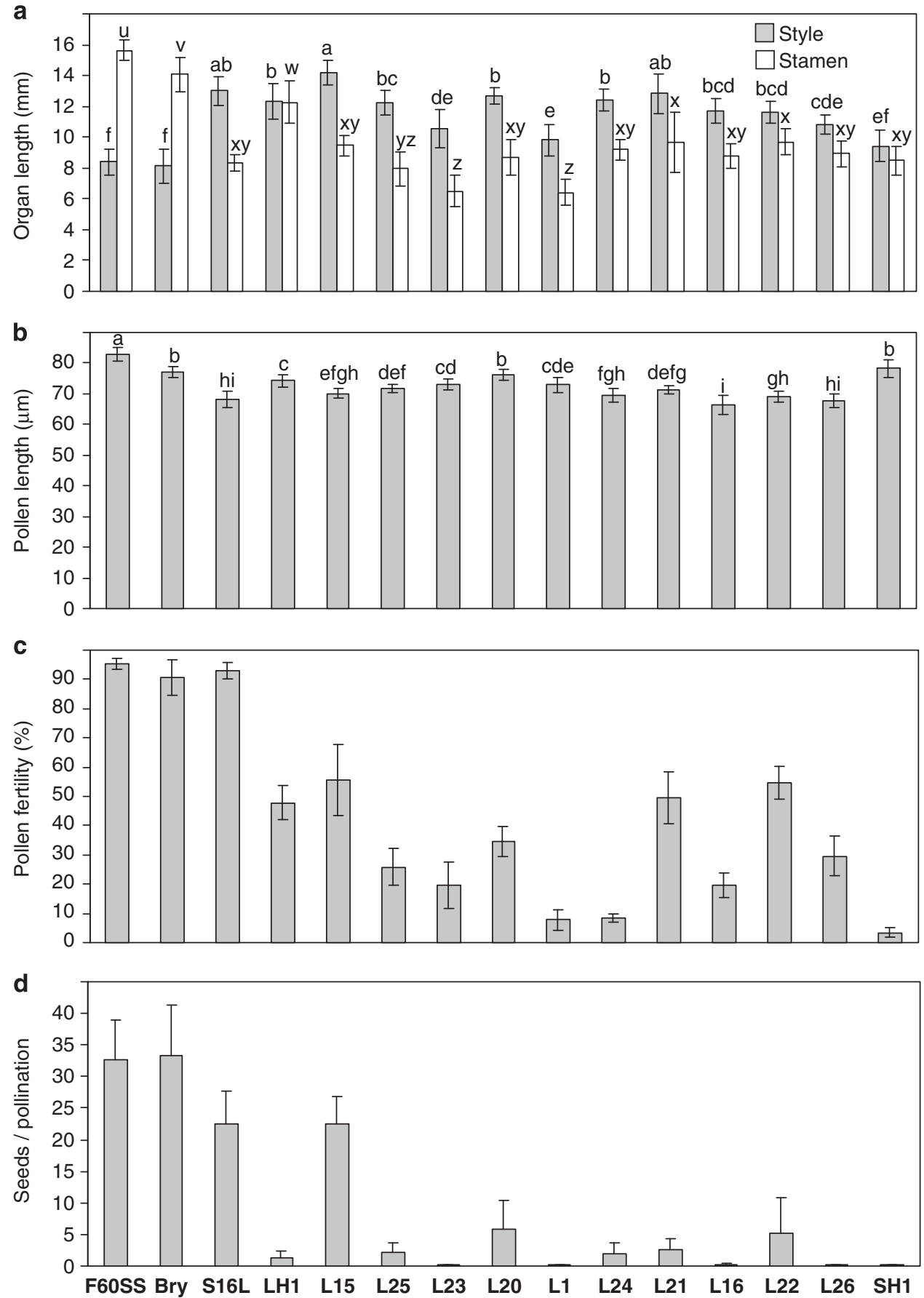

Figure 5 Means (+/ -1 s.d.) and ANOVA results for reproductive characters of mutants and parental plants. (a) Mean style length and stamen length. Separate 1-way ANOVAs were carried for style $\left(F_{14,135}=36.3, P<0.001\right)$ and stamen length $\left(F_{14,135}=62.9, P<0.001\right)$. $(\mathbf{b}) \mathrm{Mean}$ length of pollen grains $\left(F_{14,267}=92.1, P<0.001\right)$. (c) Mean percent pollen fertility $\left(F_{14,30}=75.6, P<0.001\right)$. $(d)$ Mean seed set $\left(F_{14,129}=97.1\right.$, $P<0.001$ ). Bars sharing the same letter are not significantly different following ANOVA and Tukey's test.

of $\sim 50 \%$ whereas one (SH1) was as low as $\sim 3.5 \%$ (Figure $5 \mathrm{c}$ ). To explore whether deletion of the $S$-locus region alone might be responsible for the reduced pollen fertility, we again exploited progeny from the cross L20 $\times$ Bry and the reciprocal. The mean percent pollen fertility of progeny with the mutation was $49.8 \pm 3.5 \%$ $(n=7$, range $30.8-58.0 \%)$ versus $88.5 \pm 2.0 \% \quad(n=27$, range $59.0-98.5 \%)\left(t_{32}=8.8, P<0.001\right)$.

The mutants showed reduced seed set, with the exception of mutant L15, which did not differ signifi- cantly from the long-styled parent, S16L (Figure 5d). Mutants L1, L23, L26 and SH1 set no seeds at all (Figure 5d). The remaining mutants did not have seed set exceeding $\sim 6$ seeds per pollination.

\section{Inheritance of mutations}

We investigated the inheritance of the $S$-locus mutations using crosses of seven of the deletion mutants and screening a total of 324 progeny. We identified only six 
Table 1 Inheritance of mutations identified using S-locus linked markers for crosses between mutants and parental plants S16L, F60SS and Bry

\begin{tabular}{llcc}
\hline Crosses & Morph & \multicolumn{2}{c}{ Number of progeny } \\
\cline { 3 - 4 } & & $\begin{array}{l}\text { Without } \\
\text { deletion }\end{array}$ & $\begin{array}{c}\text { With } \\
\text { deletion }\end{array}$ \\
\hline L20 $\times$ Bry & Long & 25 & 5 \\
Bry $\times$ L20 & Short & 15 & 1 \\
& Long & 4 & 0 \\
L20Bry-5L $\times$ F60SS & Short & 12 & 0 \\
F60SS $\times$ L20Bry-5 & Short & 29 & 1 \\
S16L $\times$ LH1 & Short & 24 & 0 \\
Bry $\times$ L1 & Long & 18 & 0 \\
& Long & 5 & 0 \\
L15 $\times$ F60SS & Short & 7 & 0 \\
F6SS $\times$ L15 & Short & 3 & 0 \\
L15 $\times$ Bry & Short & 62 & 0 \\
Bry $\times$ L21 & Long & 30 & 0 \\
L22 $\times$ Bry & Short & 32 & 0 \\
Bry $\times$ L22 & Long & 10 & 0 \\
Bry $\times$ L23 & Short & 14 & 0 \\
& Long & 17 & 0 \\
& Short & 14 & 0 \\
& Long & 11 & 0 \\
& Short & 18 & 0 \\
& Long & 10 & 0 \\
& Short & 11 & 0 \\
\hline
\end{tabular}

Maternal plants are listed first in the crosses above.

progeny (five long-styled and one short-styled) that inherited the mutation, as determined by assaying $S$-linked markers (see Materials and methods). All six progeny were derived from mutant L20 (Table 1) and only when it was used as the female parent. Crosses using one of the L20 progeny possessing the deletion (plant L20Bry-5L) as a female parent to F60SS produced one short-styled plant, which inherited the S-locus mutation $(n=30)$. No progeny inherited the mutation when L20Bry-5L was the pollen parent $(n=24)$ (Table 1$)$.

In summary, 378 progeny were assayed to study the inheritance of the mutations. No mutations were transmitted to offspring using the mutants as pollen parents $(n=206)$ and only seven (five long- and two short-styled) of 172 progeny inherited the mutation using the mutants as ovule parents. All of these progeny carried the mutation of L20.

Crosses made in an effort to produce a mutant homozygous for the $S$-locus deletion did not yield any such progeny $(n=154)$. Although some progeny carried one copy of the deletion, it was transmitted through the ovules, not the pollen.

\section{Discussion}

We have generated 12 floral mutants using X-ray mutagenesis and have shown that they are missing one or more $S$-linked molecular markers indicating they are deletion mutants. We believe this study represents the most extensive series of $S$-locus deletions produced for any heterostylous species. Although X-rays can also produce chromosome rearrangements, our mutant screen was likely biased towards detection of deletions. Five of the mutants generated had relatively large deletions (Figure 3). Using the estimates of $650 \mathrm{~kb} / \mathrm{cM}$ in Turnera subulata (Labonne et al., 2008), the size of the deletions in these five mutants is predicted to be greater than $7 \mathrm{mb}$. Mutants carrying similar-sized deletions have been reported in an extensive mutagenesis study in Arabidopsis thaliana (Naito et al., 2005).

The genetic architecture of distyly has been explored, especially in Primula, by analysing the inheritance of rare recombinants at the $S$ supergene (Ernst, 1955; Dowrick, 1956). The production of deletion mutants, however, provides another unexploited means of exploring the genetic architecture of distyly. Under the Primula $S$ supergene model, the genotype of the short-styled morph at the S-locus is GPA/gpa whereas long-styled plants are $g p a / g p a$, where $G / g$ determines style length and its incompatibility, $P / p$ determines pollen size and its incompatibility and $A / a$ determines stamen length (Dowrick, 1956; Lewis and Jones, 1992; Barrett and Shore, 2008). In Turnera, genetic studies are consistent with the hypothesis that a supergene comprised of at least two genes, determines distyly (Shore and Barrett, 1985; Tamari et al., 2005; Shore et al., 2006). In this study, 10 of the X-ray generated floral mutants had the long-styled phenotype indicating that all the $S$ components of the putative supergene have been deleted. Long-styled mutant L22 was the only deletion mutant possessing $R P 81 E 18$, a marker, which co-segregates with the S-locus in a family of 2013 progeny (Labonne et al., 2009). This indicates that, although RP81E18 is extremely tightly linked, it lies just outside of the $S$-locus, as suggested by Labonne et al. (2009).

Under the supergene model, deletion or generation of a non-functional form of the dominant $G$-allele would result in the production of a long homostyle having the genotype $g^{\text {del } P A / g p a, ~ w h e r e ~} g^{\text {del }}$ represents the deleted/ mutated allele. Such a plant would possess the style length and style incompatibility of a long-styled plant, but would have all other characteristics of a short-styled plant. The long homostyle (LH1) generated here appears to possess such a mutation, $g^{\text {del }}$. Pollen of LH1, however, is compatible with styles of the short-styled morph, producing considerably greater seed set compared with pollinations of the long-styled morph, with which it is largely incompatible (Figures 3 and 5). Interestingly, this incompatibility phenotype suggests that LH1 has a mutation not only at the $G$ locus but also at $P$, which is the locus determining pollen incompatibility behaviour and pollen size, originally postulated for Primula (Dowrick, 1956). As the mutation carried by LH1 did not transmit to its progeny, we cannot exclude the possibility that the pollen incompatibility response of LH1 is the result of a mutation elsewhere in the genome.

If both the floral phenotype and incompatibility behaviour of mutant LH1 is the result of a single deletion in the $S$-locus, then this indicates that a $P$-locus may also occur in Turnera subulata. The likely gene order would be GPA as the deletion would take out two adjacent genes. LH1 has pollen significantly greater in size than that of the long-styled parent, but significantly smaller than that of the short-styled parental plants (Figure 5b). Therefore, we cannot determine with certainty whether separate genes for pollen size and its incompatibility occur at the putative $P$ locus in T. subulata, as may occur in Primula Tommasinii (Kurian and Richards, 1997).

The occurrence of pollen of intermediate size is difficult to rationalize in terms of a single $P$-locus being the sole determinant of pollen size. This finding could 
suggest that pollen size is determined by more than one gene. Indeed, five of the long-styled progeny from the cross L20 $\times$ Bry, which carry the mutation of L20 have pollen significantly greater in size than the long-styled progeny without the mutation. This strongly supports the notion that additional gene(s) determining pollen size occur and they may reside in the vicinity of the S-locus.

Short homostyles can arise via deletions of the $A$ component of the $S$ supergene or both the A and $P$ subunits (Dowrick, 1956). Our SH1 short homostyle, however, appears to have a deletion of the entire S-locus region. We believe that $\mathrm{SH} 1$ is a long-styled plant with an unusually short style. The five mutants possessing large deletions that include markers RP45G6 and RP95K7, all have their stigmas and anthers in closer proximity than the remaining long-styled mutants (except L21) (Figures 3 and 5a). SH1 may therefore represent the extreme of this situation. Its style incompatibility behaviour is also like that of a long-styled plant. The reduced stigmaanther separation of these five long-styled mutants suggests that gene(s) residing outside the $S$-locus (on the RP45G6 side) may influence the lengths of styles and stamens. Modifier genes outside of the $S$-locus have been reported to affect style length in Primula sinensis and Fagopyrum esculentum (Mather, 1950; Matsui et al., 2004, 2007).

It has previously been shown that a style polygalacturonase and an $\alpha$-dioxygenase display short-specific expression patterns and appear to be upregulated by the S-allele (Athanasiou et al., 2003; Khosravi et al., 2004; Tamari and Shore, 2004). Neither gene occurs in the vicinity of $S$-locus. The absence of these proteins from styles of all long-styled mutants and LH1 supports the hypothesis that both genes are regulated by the $S$-allele, possibly the putative $G$ locus, or a gene tightly linked to it. This continues to suggest a possible role for the polygalacturonase and $\alpha$-dioxygenase in distyly.

Inheritance studies yielded only seven progeny possessing an $S$-locus mutation. All progeny were derived from mutant L20, when used as the female parent. Mutant L20 has one of the smallest deletions. Three other mutants (LH1, L23 and L25) possessed deletions of a comparable size (Figure 3 ), but set little or no seeds when used as female parents (Figure 5) and we could obtain only few, if any, progeny from crosses in this direction. Naito et al., (2005) postulated that non-transmission of deletions in Arabidopsis thaliana could be due to the knock out of genes required for ovule viability. In our study, the lack of transmission of mutations from the remaining deletion mutants (in the female direction) and the transmission bias against the L20 deletion, could similarly be the result of such genes. It is also possible that non-transmission is caused by the reduced viability of embryos, and/or seeds heterozygous for the deletion.

We did not observe the transmission of any of the mutations through pollen. Mutagenesis is known to lead to poor male transmission (Stadler and Roman, 1948) and can cause male sterility (Nasrallah et al., 2000; Koorneef, 2005; Naito et al. 2005). Furthermore, Mottinger (1969) noted that X-ray deletions affect the ability of pollen tubes to compete with those that do not possess the deletion. The reduced pollen fertility of all the mutants and the seven progeny ( $\sim 50 \%$ pollen fertility) bearing the mutation of L20 strongly suggests that non-transmis- sion may be a direct result of deletion of the S-locus and/or adjacent genes causing pollen sterility.

Naturally occurring and induced $S$-locus mutants have proved to be a valuable resource in studies of homomorphic SI systems (Goring et al., 1993; Nasrallah et al., 1994; Sassa et al., 1997; Golz et al., 2000, 2001; Ushijima et al., 2004; Sonneveld et al., 2005; Hauck et al., 2006). In heteromorphic SI systems, the genes determining distyly and tristyly have not yet been discovered (Barrett and Shore, 2008; Labonne et al., 2009). To identify the genes controlling distyly, we have initiated chromosome walking in Turnera (Labonne et al., 2009). Similar approaches are being used in Primula and Fagopyrum (Li et al., 2007; McCubbin, 2008; Yasui et al., 2008). Once a bacterial artificial chromosome contig of the $S$-locus region is assembled, the mutants generated will be invaluable in narrowing the specific region of the contig containing the S-locus genes of T. subulata. Mutant LH1, which we predict to have a deletion breakpoint within the $S$-locus, should aid in identification of the gene determining stamen length since, unlike the other mutants, it has a non-mutant stamen length phenotype.

\section{Conflict of interest}

The authors declare no conflict of interest.

\section{Acknowledgements}

We thank Arthur Hilliker for advice, and Alina Goultiaeva, Scott McClure, Lusine Zakharyan and Darya Safavian for technical assistance. We also thank Claudia Ratti for photography. This work was funded by an NSERC grant to JS Shore.

\section{References}

Athanasiou A, Shore JS (1997). Morph-specific proteins in pollen and styles of distylous Turnera (Turneraceae). Genetics 146: 669-679.

Athanasiou A, Khosravi D, Tamari F, Shore JS (2003). Characterization and localization of short-specific polygalacturonase in distylous Turnera (Turneraceae). Am J Bot 90: 675-682.

Barrett SCH, Shore JS (1987). Variation and evolution of breeding systems in the Turnera ulmifolia L complex (Turneraceae). Evolution 41: 340-354.

Barrett SCH, Shore JS (2008). New insights on heterostyly: Comparative biology, ecology and genetics. In: FranklinTong VE (ed). Self-Incompatibility in Flowering Plants: Evolution Diversity And Mechanisms. Springer-Verlag: Berlin. pp 3-32.

de Nettancourt D (1977). Incompatibility in Angiosperms. Springer-Verlag: New York.

Dowrick VPJ (1956). Heterostyly and homostyly in Primula obconica. Heredity 10: 219-236.

Ernst A (1955). Self-fertility in monomorphic Primulas. Genetica 27: 391-448.

Fesenko NN, Fesenko IN, Ohnishi O (2006). Homostyly of two morphologically different lineages of Fagopyrum homotropicum Ohnishi is determined by locus 54 , which is an S-locus related gene in the linkage group \# 4. Fagopyrum 23: 11-15.

Goring DR, Glavin TL, Schafer U, Rothstein SJ (1993). An S receptor kinase gene in self-compatible Brassica napus has a 1-bp deletion. Plant Cell 5: 531-539.

Golz JF, Clarke AE, Newbigin E (2000). Mutational approaches to the study of self-incompatibility: revisiting the pollen-part mutants. Ann Bot 85: 95-103. 
Golz JF, Oh H-Y, Su V, Kusaba M, Newbigin E (2001). Genetic analysis of Nicotiana pollen-part mutants is consistent with the presence of an $S$-ribonuclease inhibitor at the $S$-locus. Proc Natl Acad Sci USA 98: 15372-15376.

Hauck NR, Ikeka K, Tao R, Iezzoni AF (2006). The mutated $S_{1}$ haplotype in sour cherry has an altered $S$-haplotype-specific F-box protein gene. J Heredity 97: 514-520.

Khosravi D, Joulaie R, Shore JS (2003). Immunocytochemical distribution of polygalacturonase and pectins in styles and pollen of distylous and homostylous Turneraceae. Sex Plant Reprod 16: 179-190.

Khosravi D, Yang C-C, Siu KWM, Shore JS (2004). High level of $\alpha$-dioxygenase in short styles of Turnera spp. Int J Plant Sci 165: 995-1006.

Koorneef M (2005). Classical mutagenesis in higher plants. In Gilmartin PM, Bowler C (eds). Mol Plant Biol V1. Oxford University Press, Oxford. pp 1-11.

Kurian V, Richards AJ (1997). A new recombinant in the heterostyly 'S' supergene in Primula. Heredity 78: 383-390.

Labonne JDJ, Hilliker AJ, Shore JS (2007). Meiotic recombination in Turnera (Turneraceae): extreme sexual difference in rates, but no evidence for recombination suppression associated with the distyly $(S)$ locus. Heredity 98: 411-418.

Labonne JDJ, Vaisman A, Shore JS (2008). Construction of a first genetic map of distylous Turnera and a fine-scale map of the S-locus region. Genome 51: 471-478.

Labonne JDJ, Goultiaeva A, Shore JS (2009). High-resolution mapping of the $S$-locus in Turnera leads to the discovery of three genes tightly associated with the S-alleles. Mol Genet Genomics 281: 673-685.

Lewis D, Jones DA (1992). The genetics of heterostyly. In: Barrett SCH (ed). Evolution and Function of Heterostyly. Springer-Verlag: New York, pp 129-150.

Li J, Webster M, Furruya M, Gilmartin PM (2007). Identification and characterization of pin and thrum alleles of two genes that co-segregate with the Primula S-locus. Plant I 51: 18-31.

Mather K (1950). The genetical architecture of heterostyly in Primula sinensis. Evolution 4: 340-352.

Matsui K, Tetsuka T, Nishio T, Hara T (2003). Heteromorphic incompatibility retained in self-compatible plants produced by a cross between common and wild buckwheat. New Phytol 159: 701-708.

Matsui K, Nishio T, Tetsuka T (2004). Genes outside the $S$ supergene suppress $S$ functions in buckwheat (Fagopyrum esculatum). Ann Bot (London) 94: 805-809.

Matsui K, Nishio T, Tetsuka T (2007). Use of self-compatibility and modifier genes for breeding and genetic analysis in common buckwheat (Fagopyrum esculatum). JARQ 41: 1-5.

McCubbin AG (2008). Heteromorphic self-incompatibility in Primula: twenty-first century tools promise to unravel a classic nineteenth century model system. In: Franklin-Tong VE (ed). Self-incompatibility in Flowering Plants: Evolution, Diversity and Mechanisms. Springer: Berlin. pp 289-308.

Mottinger JP (1969). The effects of $X$ rays on the bronze and shrunken loci in maize. Genetics 64: 259-271.
Naito K, Kusaba M, Shikazono N, Takano T, Tanaka A, Tanisaka T et al. (2005). Transmissible and nontransmissible mutations induced by irradiating Arabidopsis thaliana pollen with $\gamma$-rays and carbon ions. Genetics 169: 881-889.

Nasrallah JB, Rundle SJ, Nasrallah ME (1994). Genetic evidence for the requirement of the Brassica S-locus receptor kinase gene in the self-incompatibility response. Plant J 5: 373-384.

Nasrallah ME, Kandasamy MK, Chang M-C, Stadler Z, Lim S, Nasrallah JB (2000). Identifying genes for pollen-stigma recognition in crucifers. Ann Bot 85: 125-132.

Nomura Y, Hatashita M, Inoue M (2002). Production of selfcompatible common buckwheat by ion exposure. Fagopyrum 19: $43-48$.

SAS Institute Inc (2004). SAS 913 Help and Documentation, Cary. SAS Institute Inc: NC.

Sassa H, Hirano H, Nishio T, Koba T (1997). Style-specific selfcompatible mutation caused by deletion of the S-RNase gene in Japanese pear (Pyrus serotina). Plant J 12: 223-227.

Sharma KD, Boyes JW (1961). Modified incompatibility of Buckwheat following irradiation. Can J Bot 39: 1241-1246.

Shore JS, Barrett SCH (1985). The genetics of distyly and homostyly in Turnera ulmifolia L Turneraceae). Heredity 55: 167-174

Shore JS, Arbo MM, Fernandez A (2006). Breeding system variation, genetics and evolution in the Turneraceae. New Phytol 171: 539-551.

Sonneveld T, Tobutt KR, Vaughan SP, Robbins TP (2005). Loss of pollen-S function in two self-compatible selections of Prunus avium is associated with deletion/mutation of an $S$ haplotype-specific F-box gene. Plant Cell 17: 37-51.

Stadler LJ, Roman H (1948). The effect of X-rays upon mutation of the gene A in maize. Genetics 33: 274-303.

Tamari F, Athanasiou A, Shore JS (2001). Pollen tube growth and inhibition in distylous and homostylous Turnera and Piriqueta (Turneraceae). Can I Bot 79: 578-591.

Tamari F, Shore JS (2004). Distribution of style and pollen polygalacturonases among distylous and homostylous Turnera and Piriqueta spp. (Turneraceae). Heredity 92: 380-385.

Tamari F, Khosravi D, Hilliker AJ, Shore JS (2005). Inheritance of spontaneous mutant homostyles in Turnera subulata $\mathrm{x}$ krapovickasii and in autotetraploid T. scabra (Turneraceae). Heredity 94: 207-216.

Ushijima K, Yamane H, Watari A, Kakehi E, Ikeda K, Hauck NR et al. (2004). The $S$ haplotype-specific F-box protein gene, $S F B$, is defective in self-compatible haplotypes of Prunus avium and $P$ mume. Plant J 39: 573-586.

Yasui Y, Mori M, Matsumoto D, Ohnishi O, Campbell CG, Ota T (2008). Construction of a BAC library for buckwheat genome research- an application to positional cloning of agriculturally valuable traits. Genes Genet Syst 83: 393-401.

Wang Y, Scarth R, Campbell C (2005). $S^{h}$ and $S_{c}$-Two complementary genes that control self-compatibility in Buckwheat. Crop Sci 45: 1229-1234.

Woo SH, Adachi T, Jong SK, Campbell CG (1999). Inheritance of self-compatibility and flower morphology in an inter-specific buckwheat hybrid. Can I Plant Sci 79: 483-490. 